\title{
JANÁČEK'S 'SLOVENIAN' PUPIL EMERIK BERAN AND HIS FORGOTTEN OPERA MELUSINA
}

Given the extremely slow development in Slovenian opera production, it seems one can count on the fingers of one hand the operas ranked among the fundamental works of opera literature in Slovenia at the end of the $19^{\text {th }}$ century. ${ }^{1}$ Due to the explicit lack of original Slovenian opera works, all those unstaged works lying in domestic musical archives are naturally all the more precious. One of these is by all means the grand romantic opera Melusina by Czech composer Emerik Beran, which is regretfully still lying forgotten in the musical archives of the University Library in Maribor. Although it was written abroad and is the work of a Czech musical emigrant who spent the greater part of his life in Slovenia, it by all means deserves more detailed treatment. ${ }^{2}$

The story about the beautiful Melusina was a frequent theme of many European legends as far back as in the Middle Ages. The most famous medieval literary version was written by Jean d'Arras and dates between 1382 and $1394 .{ }^{3}$ Particu-

1 In the period of Slovenian national awakening, two operettas were written on Slovenian soil - Vilhar's Jamska Ivanka (1850) and Tičnik by Benjamin Ipavec (1864). Both of these works, however, as well as Teharski plemiči, which was set to music by Ipavec some time later, are considered quite unexceptional both in the musical and dramaturgical sense. The qualities of a national opera could perhaps be found in Foerster's Gorenjski slavček, which had initially been conceived as an operetta (1872) and was not remade into an opera until more than two decades later (1896). Risto Savin, on the other hand, in his second opera, Lepa Vida (1907), chose to follow a somewhat different and rather independent path to national opera. Indeed, the first operas of Fran Gerbič and Viktor Parma should also be mentioned. KOTER, Darja. Glasbeno-gledališka režija na Slovenskem: od diletantizma Dramatičnega društva do poskusov profesionalizacije v Deželnem gledališču, Muzikološki zbornik 46 (2010) 1, Ljubljana 2010, p. 59.

Article that discusses the above-mentioned topic in more detail was published in Muzikološki zbornik in 2010. WEISS, Jernej. Neuprizorjena opera Melusina Emerika Berana. Muzikološki zbornik 46 (2010) 1, Ljubljana 2010, pp. 73-85. See also: WEISS, Jernej. Tudi Slovenci imamo svojo Rusalko, pardon, Melusino. Imaginacija narave v umetnosti ali 'Glasba naj posnema naravo $v$ njenem načinu delovanja'. 27 $7^{\text {th }}$ Slovenian Music Days, Ljubljana 2012, pp. $96-103$.

In 1456 this literary work was translated into German, and around 1500 into English. WHI- 
larly at the beginning of the $19^{\text {th }}$ century, this fairy tale attracted immense attention upon the reappearance of interest in one of the principal doctrines of the enlightenment retour à la nature, and consequently underwent numerous remakes by some of the leading European artists. In Central Europe, Goethe's remake of the fairytale entitled Die Neue Melusine (1807) was especially resounding. ${ }^{4}$ This version also inspired certain writers of librettos, among whom I should mention in particular one of the leading Vienna poets of the $19^{\text {th }}$ century, Franz Grillparzer, who is also the author of the libretto of Beran's opera Melusina.

Grillparzer, who as the writer of texts at the Burgtheater in Vienna was certainly not musically analphabeth, ${ }^{5}$ had initially intended this libretto for the never-to-be second opera of Ludwig van Beethoven. Their personal acquaintance dates back to 1808 , when the artists resided in the same house at Grinzinger Straße 64 in Vienna. ${ }^{6}$ However, the two famous artists did not collaborate more intensively until the successful performance of Fidelio in Vienna in 1823 when Beethoven turned to Grillpartzer in his desire for a new opera libretto. So in March 1823 Grillpartzer completed the libretto and named it Melusina: Romantische Oper in drei Aufzügen. ${ }^{7}$

TAKER, Paul K. The tragic artist in Grillparzer's 'Melusina'. Monatshefte für Deutsche Unterricht, Deutsche Sprache und Literatur, 1958, vol. 1, no. 2.

Ludwig van Beethoven, being Goethe's good friend, was familiar with the legend Die neue Melusine, published in Goethe's novella, Wilhelm Meisters Wanderjahre. MACARDLE, Donald W. Beethoven and Grillparzer. Music \& Letters, 1959, vol. 40, p. 45.

$\mathrm{He}$ is thus believed to have influenced even the casting of individual singing roles there. HÜTTNER, Johann. Zur Aufführungspraxis im Wien des frühen 19. Jahrhunderts am Beispiel von Franz Grillparzer und Ferdinand Raimund. Theater und 19. Jahrhundert. Hildesheim, 2009, p. 61.

6 Today, the house is named Beethoven-Grillparzer Haus. In memory of their first meeting, Franz Grillparzer wrote: „Das erste Mal, daß ich Beethoven sah, war in meinen Knabenjahren - es mochte in den Jahren 1804 oder 5 gewesen sein-und zwar bei einer musikalischen Abendsunterhaltung im Hause meines Onkels, Josef Sonnleithner, damaligen Gesellschafters einer Kunst- und Musikalienhandlung in Wien. Außer Beethoven befanden sich noch Cherubini und Abbé Vogler unter den Anwesenden. Er (Beethoven) war damals noch mager, schwarz und war, gegen seine spätere Gewohnheit, höchst elegant gekleidet und trug Brillen, was ich mir darum so gut merkte, weil er in späteren Zeiten sich dieser Hilfsmittel nicht mehr bediente." ("I first saw Beethoven in my youthful years - this could have been in 1804 or 1805 - at one of the evening events in the home of my uncle, Josef Sonnleithner, who at that time was the fellow partner of an art and music shop in Vienna. Also present besides Beethoven were Cherubini and Abbé Vogler. In those years he [Beethoven] was slender, dark and, contrary to his later habits, very elegantly dressed. He wore glasses, which I noticed very well then, since he no longer used this aid later on.") GRILLPARZER, Franz. BeethovenGrillparzer Haus, http://www.aeiou.at/bt-hsg-k.htm (4th October 2013).

7 GRILLPARZER, Franz. Franz Grillparzer: Sämtliche Werke. Historisch-kritische Gesamtausgabe, vol. 4, Vienna, 1925. See also: Franz Grillparzer: Sämtliche Werke, vol. 19, Vienna, 1939 and GRILLPARZER, Franz. Melusina, Romantische Oper in drei Aufzügen, http:// books.google.si/books?id=hadlmHK5h3QC\&pg=PA69\&lpg=PA69\&dq=grillparzer+melus ina\&source $=$ bl\&ots $=1$ UDAZIhqTr\&sig $=9$ FscSO3bPAZtGfpSiyxMjY1kIFE\#v=onepage \&q $\& \mathrm{f}=$ false (cit. 27th September 2013). 
Despite receiving a new libretto from Grillparzer, Beethoven subsequently did not realize his intention to set this new opera work to music. The reason being that he was not satisfied with less pronounced dramatic composition of the libretto, which was a half tragedy and half fairy tale. The libretto would probably have been completely forgotten had it not, in the $1830^{\text {'s }}$, aroused the interest of a German composer and conductor, Conradin Kreutzer ${ }^{8}$, who in 1833 wrote the music for the libretto. His Melusina, with spoken dialogues more a singspiel than a grand romantic opera, finally saw its world premiere in the same year at the Königstheater in Berlin. Its resounding success was followed by numerous performances in Vienna and elsewhere, which, among others, also encouraged Felix Mendelssohn Bartholdy to write the music for the overture of Die schöne Melusine, premiered in London on $14^{\text {th }}$ of November 1833 with great success.

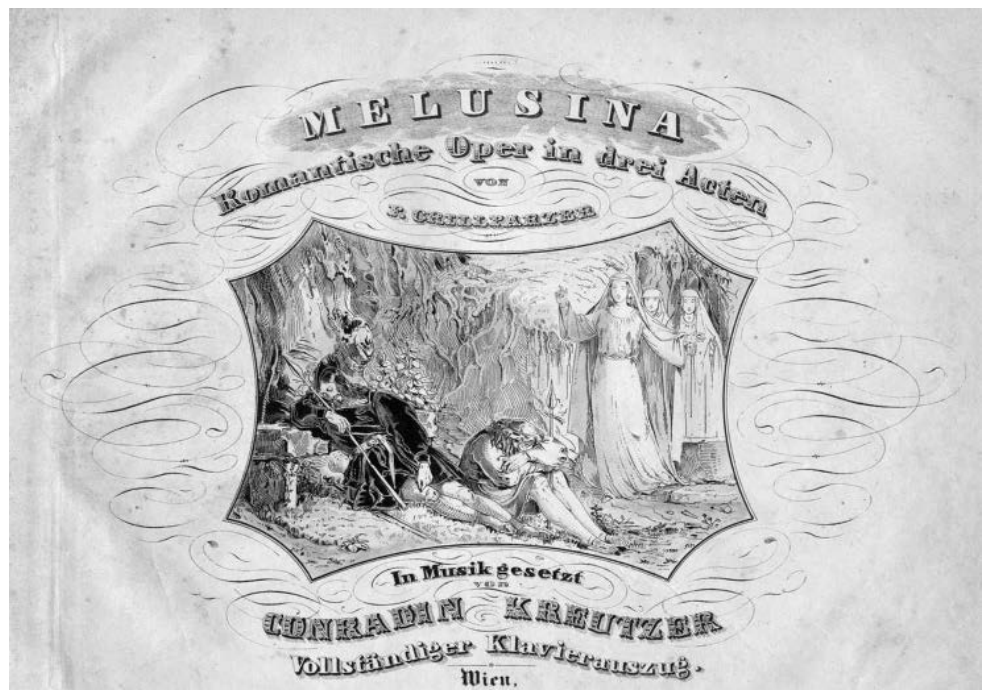

Fig. 1. Cover page of piano excerpt from Melusina by Conradin Kreutzer, Vienna 1833 (Notendrucke aus der Musikabteilung der Bayerischen Staatsbibliothek, München, Bayerische Staatsbibliothek, 2 Mus. pr. 4424).

8 Conradin Kreutzer (22. 11. 1780, Messkirch, Baden - 14. 12. 1849, Riga), German composer and conductor. He produced several successful operas in Vienna before embarking on a career as musical director to several of the smaller German courts. From 1822 he worked again in Vienna, where Libuše (1822), an uneven but not uninteresting work on the founding of the Bohemian state, gained him the directorship of the Kärntnertortheater. He also held appointments at the Theater in der Josefstadt. His greatest success was Das Nachtlager in Granada (1834), which includes some striking Romantic elements among more conventional Singspiel gestures, as does Der Verschwender (1834). BRANSCOMBE, Peter. 'Kreutzer, Conradin', The New Grove Dictionary of Music and Musicians, [cit. 17th October 2013] URL: <http://www.grovemusic.com/shared/views/article.html?from=search\&session_search_id=236400747\&hitnum=1\&section=music.15528>. 
The libretto of Melusina is naturally not the only opera libretto with a fairytale-pastoral theme about a love affair with a nymph. It reveals a close affinity with a number of other opera librettos, among which the most resounding at the beginning of the $20^{\text {th }}$ century was undoubtedly Kvapil's remake of the libretto for Dvořák's Rusalka (1901). Not just in Rusalka, from the very beginning of Czech national opera, pastoral elements were an important component of Czech opera librettos. ${ }^{9}$ For example, some of Smetana's operas, such as Hubicka (1876) and Tajemství (1878), already reveal some typical illustrations of nature that are linked primarily to experiencing the nocturnal world of magnificent Czech forests. The magic fairy tale world later attracted many other Czech opera composers, among them certainly Zdeněk Fibich, in his opera Šárka (1897) and of course Leoš Janáček in his operas Šárka (1925) and Př́hody Lišky Bystroušky (1924).

It is thus not surprising that also Emerik Beran was inspired by a love fairy tale between a nymph and a prince, which led him to write the opera Melusina. After completing his studies under Leoš Janáček at the Organ School in Brno, Beran on the recommendation of his mentor in 1890 became assistant teacher at the Organ School. ${ }^{10}$ Although Janáček's first operas were not decisively influenced by the Czech opera production of that time, the Městské divadlo in Brno was one of the most modern theatres in the entire monarchy because of its modern stage equipment. ${ }^{11}$ The Moravian capital thus provided Beran very favourable conditions for his operatic development where, as a substitute violoncellist, he also gained practical experience playing in the opera's orchestra. This allowed him to become acquainted with some of the leading works in the opera's standard repertoire.

So it was certainly not surprising that the favourable conditions for the flourishing of opera production in Brno soon encouraged Beran to make his first attempts as opera composer. Some sketches of his Melusina can even be traced to the period before Beran's admission to the Organ School in 1885. ${ }^{12}$ However he completed Melusina, the only opera work in his output, in the fall of 1896, so it took him more than a decade to finish the opera. This means that Beran had already finalised Melusina in Brno two years before accepting the post of music teacher at the National Men's Teaching School in Slovenian town Maribor in the fall of 1898, where he taught, among others, Slavko Osterc and some other leading Slovenian composers in the period between the two wars.

Although in the 1897/98 season the staging of Beran's opera had been announced in the then representational Czech music newspaper Dalibor, it was never realised for unknown reasons. However, the numerous concert reviews inclined towards

9 TYRRELL, John. Czech Opera, Cambridge University Press, Cambridge 1988, pp. 154155.

10 WEISS, Jernej. Emerik Beran (1868-1940): Samotni svetovljan. Maribor: Študentska založba Litera, 2008, p. 26.

11 Ibid., p. 18.

12 Ibid., p. 98. 
Beran's musical- productive and reproductive works indicate that the composer enjoyed a strong presence in the musical conscience of the Brno bourgeoisie in 1897 and $1898 .{ }^{13}$ It is all the more surprising that in spite of his great compositional and reproductive achievements (as choirmaster, conductor, and elsewhere), as well as the reputation he enjoyed as a teacher in the capital of Moravia, he decided to leave Brno after 1898 and settle in then more or less provincial Maribor. ${ }^{14}$

Particularly Beran's former professor and later his teaching colleague and friend, Leoš Janáček, kept encouraging him to stage the premiere of Melusina. On several occasions he urged him to complete the piano score of the opera which, ${ }^{15}$ mostly due to his numerous teaching obligations, Beran only managed to complete after Janáček's death. This could be one of the reasons for the nonstaging of the opera. In their very extensive correspondence, ${ }^{16}$ Beran asks Janáček on several occasions whether the premiere of Melusina could be staged in Brno, where he had already succeeded as a composer. Although Janáček was then already an undisputed authority in Brno's opera circles, his reputation did not helped him to influence the theatre management there and include Beran's Melusina in the opera repertoire. Beran thus continuously endeavoured for Melusina's staging and sent it to various addresses, but always met with refusal.

Janáček in this way understood him quite well since he shared a similar fate after the premiere of Jenúfa (Jeji pastorkyña) in 1904. ${ }^{17}$ It is therefore not surprising that almost the entire correspondence between them was focused on the worries caused

13 The committee of the Brünner Musikerbund society congratulated Beran in writing on his 'great success' in the rendition of Legende $I$ at the city theatre, adding that the society was honoured to have Beran among its members. Ibid., p. 103.

In addition to existential reasons, Beran was impelled to change his abode primarily for reasons of the heart. His Melusina was named Roza Stvrtniček. Ibid., p. 30.

15 Leoš Janáček, Brno, 4th June 1914, Glasbena zbirka, Univerzitetna knjižnica Maribor.

16 WEISS, Jernej. The forgotten correspondence between two friends: Leoš Janáček (18541928) and Emerik Beran (1868-1940). Muzikološki zbornik 41 (2005) 1, Ljubljana, 2005, pp. 91-98. See also: WEISS, Jernej. The transctiption of the Correspondence between Leoš Janáček (1854-1928) and Emerik Beran (1868-1940). Muzikološki zbornik 42 (2006) 1, Ljubljana, 2006, pp. 147-164.

17 After the first performance of Jenưfa (Jeji pastorkyña), Janáček also faced a similar fate while attempting for over a decade in vain to have the opera staged with the Director of the Opera of the Prague National Theatre, Karel Kovařovic. The latter continually expressed the technical shortcomings of the score only allowing the premiere after he himself had revised the score. He thus conducted the premiere performance of the opera in Prague on 26th May 1916. The Prague staging widely opened the door of the European opera stages for Jenifa. TYRRELL, John. Janáček: Years of a Life, The lonely blackbird, vol. 1. London: Faber and faber, 2006, pp. 604-618. It is interesting that among the first performances of the opera abroad, we can also find the premiere staging of Jenuifa on the stage of the Ljubljana Opera house on 28th October 1922. WEISS, Jernej. The forgotten correspondence between two friends: Leoš Janáček (1854-1928) and Emerik Beran (1868-1940). Muzikološki zbornik 41 (2005) 1, Ljubljana, 2005, p. 95. 
by the nonstaging of Melusina.${ }^{18}$ Beran's truly great desire to stage the premiere of his sole opera is also evident in his further correspondence with Janáček's wife, Zdenka Janáčkova, in the 30's. In his letters, Beran not only reports on family and professional matters, but also requests her assistance in connection with the staging of his opera. ${ }^{19}$ In one of his letters he writes that he would be truly happy if his Melusina could finally be staged. ${ }^{20}$ Thanks to her mediation, Beran supposedly discussed the performance of his opera with the director of the Brno opera, František Neumann, who was quite reserved as regards its staging in Brno theatre. ${ }^{21}$

Beran's great desire to stage his only opera is also evident in the fact that despite countless refusals, he prepared the complete materials for the possible staging of Melusina. Though precise reasons for its nonstaging were never actually given, the main reason for its refusal by various opera houses can probably be attributed to the composer's anonymity in the area of stage production. Another significant reason is probably concealed in the fact that despite its German libretto, the opera probably did not comply with the programme policy that supported the predominance of German opera theatres in the period up to the First World War, since its composer was of Czech origin. The opera was also not included in the extremely rare stagings of Czech operas in that period, when only the most popular works from Czech opera composers were generally put on the repertoire. It should be noted that the two theatres situated in the towns where Beran's creative activities had left a strong imprint - Brno and Maribor - remained firmly in German hands until the end of the First World War. ${ }^{22}$ It was therefore practically impossible to expect, at the turn of the $19^{\text {th }}$ to the $20^{\text {th }}$ centuries, the staging of an opera that was written by a more or less unknown Czech composer. One of the reasons for the nonstaging of Melusina could, of course, lie also in the lack of quality of the Beran's opera, yet it nevertheless does not seem probable that in opera theatres would be willing to take time for a more detailed analysis of the score.

18 From the creation of Melusina in 1896, Beran had consistently endeavoured to have it staged and had sent the opera to various addresses, but was refused each time. At last, he offered it to the theatre in Zagreb just prior to the beginning of World War I, but the opera was not included in the theatre programme. After his last unsuccessful attempt, he abandoned all efforts for its staging for more than a decade. Ibid., pp. 94-95.

19 Ibid., p. 97.

20 BERAN, Emerik. Correspondence of Leoš Janáček, Ljubljana, 22nd December 1936. Music History Department of the Moravian Museum in Brno.

21 WEISS, Jernej. The forgotten correspondence between two friends: Leoš Janáček (1854-1928) and Emerik Beran (1868-1940), Muzikološki zbornik 41 (2005) 1, Ljubljana 2005, p. 97.

22 In Moravian towns, the fights between the German majority and the Czech minority were the worst in the towns in Moravia in the nineties of the 19th century. The conflicts were especially grave in Brno where the Germans maintained the strongest influence with a convincing majority. In the provincial assembly, it was only in 1905 that the two nations decided on negotiations, which led to a partial settlement ('Ausgleich') by changing the electoral order and a compromised arrangement on some other disputed issues. LÉBL, Vladimir. Hudba a společnost. In Dějiny české hudební kultury 1890/1945. Prague, 1972, pp. 253-260. 


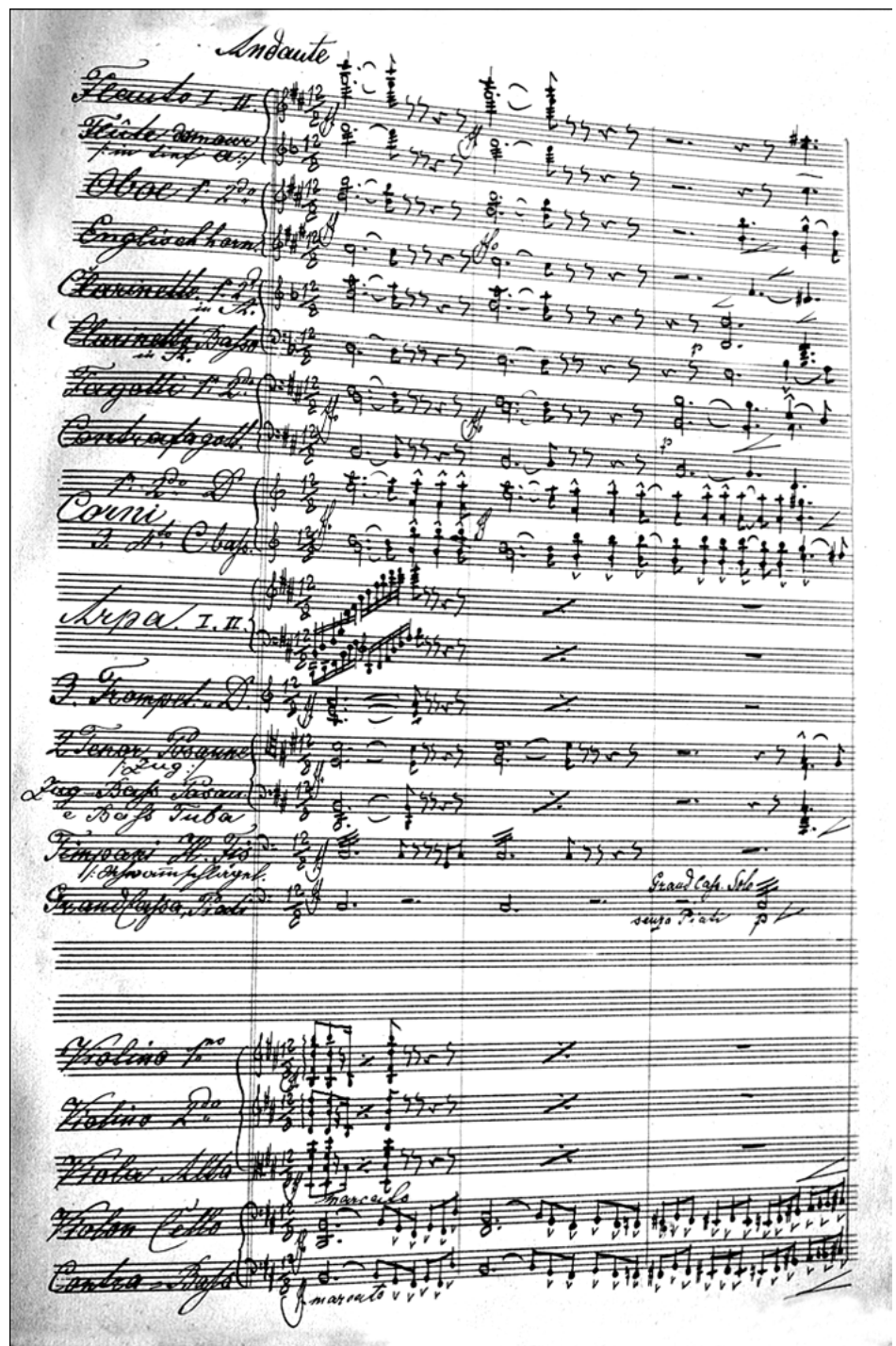

Fig. 2. First page of Overture to Beran's Melusina, Brno 1896 (Beran's manuscript, Maribor, University Library Maribor).

Beran's compositions reflect a strong individuality, which both in compositional as well as conceptual and aesthetic issues continues to follow its own laws. Both Beran and Janáček were aware of varying aesthetic views and the compositional directions stemming from them. For this reason they rarely discussed, in their extensive correspondence, more concrete compositional or aesthetic issues. Beran more or less remained within the traditional boundaries. Janáček however always appreciated his originality in composition. 
The only part of the Beran's Melusina that has so far been recorded and published was the overture. ${ }^{23}$ It reveals some essential characteristics of Beran's compositional style. Its very dramatic beginning is reminiscent of some of Wagner's overtures. It is highly effective as a mood introduction to the opera. Particularly owing to its grand instrumentation, the composer was able to achieve convincing colour effects.

On the other hand the composer did not omit numerical form of the opera. The structure of the first act, if we observe its main contours, is comprised of three parts and is in a certain sense symmetric. Worthy of special attention in the first act is the lively instrumental intermezzo, entitled Dancing and Singing of Nymphs, featuring a dance of fairy-tale creatures with short, repetitious motifs revealing a Slavic character.

Also the second act of the opera is composed from a sequence of alternating brief solo and choral numbers. The choruses are thus characterised by a series of repeating motifs and expressiveness that is very close to Czech romanticism. The entire story in the second act unfolds in the fairy-tale world of a castle. Some pastoral reminiscences also appear in this act - primarily in the May song sung by the country people, revealing the composer's romantic models.

The initially united last act, was subsequently divided by the composer into two parts. This expansion also points to Beran's leaning on the grand opera, which significantly influenced the development of both German and Czech romantic opera. Having admired Melusina's cantilena in the third act, the fourth act is dominated by the revelation of Melusina's secret and her farewell. Through a symphonic scheme in the last act, the composer is again using leitmotifs. However gradation seems to be somewhat missing in the last act, which is why the finale - at least to the extent that it can be felt out of the piano score - does not create any strong dramatic impression so typical of the grand romantic operas.

Being an opera enthusiast, Beran was undoubtedly well acquainted with both domestic and foreign opera literature. However he basically leaned on certain more traditional compositional-technical models, complementing these in some places with leitmotifs. This clearly proves that Beran attempted to psychologically intensify and deepen his composition.

It is surprising that before composing Melusina, Beran did not have any major experience with vocal works. The complexity of the singing parts in opera is thus quite surprising. Apparently the composer still trusted the verified formula

23 In 1957 the Society of Slovenian Composers published the Prelude to the opera Melusina. The Prelude has the following designation: Ed. DSS 1295*. For the needs of RTV Slovenia, on 19 March 2007 the RTV Slovenia Symphony Orchestra made a new recording of the Prelude to the opera led by conductor Marko Hribernik (the recording bears the designation: $\mathrm{S}-6258$ ). The endeavours to revive an awareness of Beran's significance for musical culture in Slovenia also led to the premiere concert of Beran's Prelude to Melusina (23rd Slovenian Days of Music, 21 April 2008, RTV Slovenia Symphony Orchestra conducted by Anton Nanut). 
of a typically belcanto vocal melody. So there is of course no trace of Janáček 'speech melodies' probably also because of the fact that opera was written in German and not in Czech language.

Without doubt one can sense in Melusina a sort of delayed attempt to unite the grand and romantic operas, each of which is bound to its opera element as a combined work of art. The grand opera to strongly expanded instrumentation and the expanded size of an opera work, while the romantic opera leans on mythologically coloured material filled with pastoral elements, fairy-tale creatures and a generally magical atmosphere. Beran therefore rightly categorized Melusina as a grand romantic opera, which is why it may be ranked among the most important works of some of the leading Slovenian romantic composers of that time.

Today, we once again face the question whether the staging of Melusina would be necessary. Some opera's parts would undoubtedly need to be revised before premier. However, despite its minor insufficiencies, Melusina is certainly one of the first grand romantic operas which, at the end of the $19^{\text {th }}$ century, may be attributed to one of those composers who were active in Slovenia. Being Janáček's pupil, Beran was a widely educated musician with a firm musical education, who was very well acquainted with the current opera literature of that time, which in the period of formation of Slovenian opera production was more an exception than a rule. Despite his tireless efforts to stage the opera, Beran did not live to see its premiere. More than a century after its creation opera thus still awaits its staging. So certainly the opera of the one of the first Janáček's pupils would deserve more attention from both Slovenian and Czech opera theatres.

Jernej Weiss is one of the most important foreign researchers of Czech music. Currently he works as Associate Professor for musicology at the Academy of Music in Ljubljana and at the Faculty of Education of the University of Maribor. Since 2011 he has been an editor-in-chief of the main, peerreviewed Slovene musicological periodical Musicological Annual (Muzikološki zbornik). He is an author of three scientific monographs about Czech music: Emerik Beran 1868-1949: The Lonely Cosmopolitan, Litera, Maribor 2008; Hans Gerstner 1851-1939: A Life Dedicated to Music, Litera and University of Maribor, Maribor 2010 and Czech Musicians in the 19th and Early 20th Centuries in Slovenia, Litera and University of Maribor, Maribor 2012.

\begin{abstract}
:
Janáček's 'Slovenian' pupil Emerik Beran wrote his only opera, which he entitled Melusina, in Brno in 1896. Although the opera was conceived abroad by the Czech composer, who lived most of his life in Slovenia, it certainly deserves a more detailed musical, historical and analytical discussion. In spite of its extremely interesting libretto and surprisingly advanced orchestration, at least for the then prevailing circumstances in Slovenia, Beran's opera unfortunately still lies buried in the musical archive of the University Library in Maribor, waiting for its world premiere.
\end{abstract}

Key words:

Emerik Beran, Leoš Janáček, pupil, opera, Melusina 


\section{Bibliography:}

BERAN, Emerik. Correspondence of Leoš Janáček, Ljubljana, 22nd December 1936. Music History Department of the Moravian Museum in Brno.

BRANSCOMBE, Peter. 'Kreutzer, Conradin', The New Grove Dictionary of Music and Musicians. [Online]. [Cit. 17th October 2013]. URL: <http://www.grovemusic.com/shared/views/article. html?from=search\&session_search_id=236400747\&hitnum=1\&section=music.15528>.

GRILLPARZER, Franz. Beethoven-Grillparzer Haus. [Online]. [Cit. (4th October 2013]. URL: $<\mathrm{http}: / /$ www.aeiou.at/bt-hsg-k.htm>.

GRILLPARZER, Franz. Franz Grillparzer: Sämtliche Werke, vol. 19, Vienna, 1939.

GRILLPARZER, Franz. Franz Grillparzer: Sämtliche Werke. Historisch-kritische Gesamtausgabe, vol. 4, Vienna, 1925.

GRILLPARZER, Franz. Melusina, Romantische Oper in drei Aufzügen. [Online]. [Cit. 27th September 2013]. URL: <http://books.google.si/books?id=hadlmHK5h3QC\&pg=PA69\&lpg=PA69 $\& \mathrm{dq}=$ grillparzer+melusina\&source $=$ bl\&ots $=1$ UDAZIhqTr\&sig=9FscSO3bPAZtGfpSiyxMjY1k IFE $\# \mathrm{v}=$ onepage $\& \mathrm{q} \& \mathrm{f}=$ false $>$.

HÜTTNER, Johann. Zur Aufführungspraxis im Wien des frühen 19. Jahrhunderts am Beispiel von Franz Grillparzer und Ferdinand Raimund. Theater und 19. Jahrhundert. Hildesheim, 2009.

KOTER, Darja. Glasbeno-gledališka režija na Slovenskem: od diletantizma Dramatičnega društva do poskusov profesionalizacije v Deželnem gledališču, Muzikološki zbornik 46 (2010) 1, Ljubljana 2010.

LÉBL, Vladimír. Hudba a společnost. In Dějiny české hudební kultury 1890/1945. Prague, 1972, pp. 253-260.

MACARDLE, Donald W. Beethoven and Grillparzer. Music \& Letters, 1959, vol. 40, p. 45.

TYRRELL, John. Czech Opera. Cambridge: Cambridge University Press, 1988.

TYRRELL, John. Janáček: Years of a Life, The lonely blackbird, vol. 1. London: Faber and Faber, 2006.

WEISS, Jernej. Emerik Beran (1868-1940): Samotni svetovljan. Maribor: Študentska založba Litera, 2008.

WEISS, Jernej. Neuprizorjena opera Melusina Emerika Berana. Muzikološki zbornik 46 (2010) 1, Ljubljana 2010, pp. 73-85.

WEISS, Jernej. The forgotten correspondence between two friends: Leoš Janáček (1854-1928) and Emerik Beran (1868-1940). Muzikološki zbornik 41 (2005) 1, Ljubljana, 2005, pp. 91-98.

WEISS, Jernej. The transctiption of the Correspondence between Leoš Janáček (1854-1928) and Emerik Beran (1868-1940). Muzikološki zbornik 42 (2006) 1, Ljubljana, 2006, pp. 147-164.

WEISS, Jernej. Tudi Slovenci imamo svojo Rusalko, pardon, Melusino. Imaginacija narave $v$ umetnosti ali 'Glasba naj posnema naravo v njenem načinu delovanja'. 27th Slovenian Music Days, Ljubljana 2012, pp. 96-103.

WHITAKER, Paul K. The tragic artist in Grillparzer's 'Melusina'. Monatshefte für Deutsche Unterricht, Deutsche Sprache und Literatur, 1958, vol. 1, no. 2. 